\title{
Comments
}

\section{BACK DoOR ARbitration: WHY ALLOWING NONSIGNATORIES TO UNFAIRLY UTILIZE ARbitration Clauses MAY Violate the SEVENTH AMENDMENT}

\author{
Nima H. Mohebbi*
}

\section{INTRODUCTION}

In 1925, amidst prevalent judicial hostility toward arbitration, Congress passed the Federal Arbitration Act ("FAA"). ${ }^{1}$ The FAA was enacted to address the existing judicial hostility ${ }^{2}$ by placing a premium on the enforcement of arbitration agreements, ${ }^{3}$ and expressing a federal policy favoring arbitration. ${ }^{4}$ This pro-arbitration policy has sometimes, however, trumped equitable, statutory, and even constitutional mandates.

* I would like to thank Joseph Profaizer for his invaluable guidance and astute suggestions on this topic. Many thanks are also due to Craig Reiser for his comments throughout the writing process, and to Vianney Lopez and all of the editors at the Journal who worked on this article.

1. 9 U.S.C. §§ 1-16 (2006) (originally enacted as the United States Arbitration Act, ch. 213, 43 Stat. 883 (1925)).

2. See, e.g., H.R. REP. No. 68-96 (1924) (noting judicial reluctance to enforce certain types of arbitration agreements).

3. See generally Jon O. Shimabukuro, The Federal Arbitration Act: BACKgRound AND RECENT DEVElOPMENTS (Cong. Research Serv., CRS Report for Congress Order Code RL30934, updated Aug. 15, 2003), available at http://digital.library.unt.edu/govdocs/crs/permalink/meta-crs-3879:1 (discussing the legislative history and subsequent judicial interpretation of the FAA).

4. See, e.g., Hall St. Assoc. v. Mattel, Inc., 128 S. Ct. 1396, 1402 (2008) ("Congress enacted the FAA to replace judicial indisposition to arbitration with a "national policy favoring [it] and plac[ing] arbitration agreements on equal footing with all other contracts."” (citing Buckeye Check Cashing, Inc. v. Cardegna, 546 U.S. 440, 443 (2006))); see also Frank Z. LaForge, Inequitable Estoppel: Arbitrating with Nonsignatory Defendants Under Grigson v. Creative Artists, 84 TeX. L. REv. 225, 228-29 (2005) (noting judicial resistance to enforcing arbitration agreements before and after the enactment of the FAA). 
Recently, the Supreme Court decided the case of Arthur Andersen $L L P$ v. Carlisle, holding that nonsignatories to arbitration agreements may appeal denials of motions to stay litigation under the FAA. ${ }^{5}$ In so holding, however, the Court has opened a potential floodgate by implicitly authorizing the common practice by which federal courts permit nonsignatories to take unfair advantage of arbitration clauses where they would not otherwise have a legitimate expectation to invoke such clauses. As an example of this latter phenomenon, various courts have permitted nonsignatories to compel plaintiffs to submit to binding arbitration under an application of equitable estoppel that does not require proving that the plaintiff unreasonably relied on an agreement containing a clause to arbitrate in asserting any claims. ${ }^{6}$ Moreover, this doctrine does not require the nonsignatory to prove equitable estoppel's traditional elements of misrepresentation and detrimental reliance. ${ }^{7}$

This application of equitable estoppel can be illustrated with a hypothetical example. Envision a case involving a plaintiff ${ }^{8}$ who has suffered damages pursuant to a breached contract with one party ("Party A"), and assume that the contract contains an agreement to submit all claims arising from any breach between the parties to binding arbitration. Further assume that a third party ("Party B"), who was not a signatory to the arbitration agreement, is joined in the litigation and seeks a motion to compel the plaintiff to submit the claims against her to arbitration, or seeks to stay the already-initiated litigation so that an arbitration may take place. Party B reasons essentially that overlapping allegations of factually interdependent misconduct exist between the plaintiff's claims against both Party A and Party B, and as such, the court should require the plaintiff to arbitrate his claims against Party B as well. Obviously, the parties must arbitrate if Party B's motion is granted. If Party B's motion is denied, however, Party B may appeal the denial. ${ }^{9} \quad$ This article contends that allowing nonsignatories to invoke arbitration clauses under the latter application of equitable estoppel may violate the Seventh Amendment. ${ }^{10}$

5. 129 S.Ct. 1896 (2009) (“Carlisle”).

6. See, e.g., infra Section III.B; cf. Ross v. Am. Express Co., 478 F.3d 96, 99 (2d Cir. 2007) (holding that a nonsignatory to an arbitration agreement could compel arbitration under the common law principle of equitable estoppel where claims with multiple defendants were "inextricably intertwined").

7. Id.

8. This article will use the term "plaintiff" interchangeably with "signatory" when discussing a party who is forced to arbitrate pursuant to this doctrine.

9. See 9 U.S.C. § 16(a)(1)(A)-(C) (permitting appeals of interlocutory orders denying motions to compel arbitration and to stay proceedings pending arbitration).

10. The Seventh Amendment states:

In Suits at common law, where the value in controversy shall exceed twenty dollars, the right of trial by jury shall be preserved, and no fact tried by a jury, 
The Seventh Amendment preserves the right to jury trial in federal courts for actions that existed at law ${ }^{11}$ prior to the merger of law and equity that occurred with the passage of the Federal Rules of Civil Procedure. ${ }^{12}$ By permitting nonsignatories to make unfair use of arbitration clauses, plaintiffs may lose the right to have a jury hear legal claims. This is because, in these instances, the plaintiff may not fairly anticipate having to arbitrate with a nonsignatory. The effect is a prime collateral consequence of the broad federal pro-arbitration policy, which the Supreme Court endorsed in Carlisle by refusing to categorically require that a litigant be a party to a written agreement containing an arbitration clause in order to possess an ability to stay litigation - and by logical extension, to compel arbitration - under the FAA. ${ }^{13}$

There has been little literature on this topic. One commentator, Professor Jean Sternlight, has suggested that the federal policy in favor of binding arbitration ${ }^{14}$ may in many instances have the general effect of denying litigants a right to trial by jury. ${ }^{15}$ This is because these litigants often do not knowingly or intelligently waive their right to jury trial when they are forced to arbitrate under the FAA. ${ }^{16}$ Indeed, the pro-arbitration policy in many cases trumps alternative considerations and courts frequently consider it a dispositive factor. ${ }^{17}$ The actions taken by courts in cases that apply equitable estoppel provide a convincing illustration of this aspect. Another commentator, Frank LaForge, uses these cases to illustrate that permitting nonsignatories to compel arbitration under the theory of

shall be otherwise re-examined in any Court of the United States, than according to the rules of the common law.

U.S. CONST. amend. VII.

11. See Beacon Theatres v. Westover, 359 U.S. 500, 504-07 (1959) (discussing the impact of the Declaratory Judgment Act and the Federal Rules of Civil Procedure on the analysis of standards for equitable jurisdiction).

12. See FED. R. Civ. P. 2 ("There is one form of action-the civil action.”).

13. 129 S.Ct. 1896 (2009).

14. See e.g., Hall St. Assoc. v. Mattel, Inc., 128 S. Ct. 1396, 1402 (2008) (discussing the pro-arbitration policy of the FAA).

15. See Jean R. Sternlight, Rethinking the Constitutionality of the Supreme Court's Preference for Binding Arbitration: A Fresh Assessment of Jury Trial, Separation of Powers, and Due Process Concerns, 72 Tul. L. Rev. 1, 10-19 (1997) (positing that the Supreme Court's preference for binding arbitration over litigation is unconstitutional).

16. See infra Section III.C (discussing jurisprudence of jury trial waivers). In addition, Sternlight suggests that the pro-arbitration policy preference may pose numerous other constitutional problems. See Sternlight, supra note 15, at 7 (suggesting that some binding arbitration clauses may violate the Due Process Clause and deny prospective litigants the right to an Article III judge).

17. See, e.g., Realty Trust Group, Inc. v. Ace Am. Ins. Co., 2007 U.S. Dist. LEXIS 91331, at *9 (S.D. Miss. Dec. 11, 2007) ("In general, courts recognize a strong federal policy in favor of arbitration, and any doubts about the scope of an agreement are to be resolved in favor of arbitration ....”). 
equitable estoppel is not equitable at all, principally because, as noted above, the theory lacks the requirements of misrepresentation and detrimental reliance, and confuses the actual parties at controversy. ${ }^{18}$

This article contends that a litigant's right to jury trial can be unfairly usurped partially because of LaForge's analysis that allowing nonsignatories to invoke arbitration clauses under this doctrine maintains no basis in traditional equity principles. Moreover, as a corollary to LaForge's argument, this article further contends that a party who is forced to arbitrate under the latter application of equitable estoppel cannot be said to have either knowingly waived his right to jury trial or mutually assented to an agreement to arbitrate with a nonsignatory. The FAA seems to attempt to prevent the latter consequence in the statutory text by requiring the existence of a written agreement before a party may avail itself of the ability to stay litigation or compel arbitration. ${ }^{19}$ However, just as many other cases before it, Carlisle embraced the broad federal pro-arbitration policy and rejected the latter limiting provision, implicitly sanctioning the ability of nonsignatories to divest litigants of their right to jury trial. ${ }^{20}$ This is, moreover, only one potential consequence. Worse yet, without a "written agreement" limitation, third-party nonsignatories could likely have unfettered access to arbitration clauses to which they were not initially a party.

This article proceeds as follows: Sections II.A and II.B give a brief overview of the historical origins of American arbitration law. Section II.C introduces the applicable provisions under the FAA that permit nonsignatories both to compel arbitration and to stay litigation. Section II.D discusses the Seventh Amendment and the right to trial by jury in civil actions. Finally, Section III presents the argument that the broad holding in Carlisle implicitly sanctions the common practice in federal courts of allowing nonsignatories access to arbitration clauses under a misapplication of the doctrine of equitable estoppel. Because a litigant is unfairly required to arbitrate and cannot be said to have legitimately waived his right to jury trial under these circumstances, this is but one of the opinion's foreseeable consequences that may violate the Constitution.

18. See LaForge, supra note 4, at 242-47 (distinguishing the Fifth Circuit's test in Grigson v. Creative Artists Agency, L.L.C., 210 F.3d 524 (5th Cir. 2000) from the traditional principles of equitable estoppel requiring both misrepresentation and detrimental reliance).

19. See infra Section III.A (discussing implications of equitable estoppel on the right to jury trial).

20. 129 S.Ct. 1896 (2009). 


\section{HISTORICAL ORIGINS OF AMERICAN ARBITRATION LAW}

The United States legal system acquired its early views toward arbitration from English jurisprudence. ${ }^{21}$ This procured mentality involved judicial hostility to enforcing arbitration agreements, and was the basis for the ultimate enactment of the FAA. ${ }^{22}$ The latter fact provides context for understanding both the federal pro-arbitration policy and the current preference of many courts for arbitration over litigation under a variety of circumstances, even when maintaining that preference may be inequitable and may potentially run afoul of the Constitution.

\section{A. A Brief History of Arbitration in England}

The collapse of the Roman Empire brought forth a near halt in international commerce in Europe. ${ }^{23}$ The cohesive structure of the Roman Empire was ultimately replaced with a decentralized system of regional interaction, particularly with respect to trade. ${ }^{24}$ The eleventh century, however, brought increased agricultural production, enabling society to sustain growing populations. ${ }^{25}$ In turn, urban migration increased, and merchant classes emerged. ${ }^{26}$

These merchants, separated by various barriers, needed a mechanism to facilitate trade. ${ }^{27}$ The mechanism that met this demand was the law merchant, an informal body of rules created to enforce merchant trading customs. ${ }^{28}$ Because of a lack of a uniform centralized body of governance, disputes were typically adjudicated by private arbitration. ${ }^{29}$ Merchants

21. See Jean R. Sternlight, Panacea or Corporate Tool?: Debunking the Supreme Court's Preference for Binding Arbitration, 74 WASH. U. L. Q. 637, 644-47 (1996) (discussing early American arbitration jurisprudence).

22. Id.

23. See James William ERmatinger, The Decline and Fall of the Roman Empire 68 (Greenwood Press 2004) (chronicling the history of the Roman Empire's collapse and its effect on increased regional interaction).

24. Id.

25. See Peter T. Leeson, One More Time With Feeling: The Law Merchant, Arbitration, and International Trade, 2007 INDIAN J. OF ECON. \& Bus. (SPECIAL IssuE) 29, 30 (discussing development of merchant classes that followed from increased agricultural production and urban migration).

26. Id.

27. See id. at 30 ("Merchants throughout Europe were separated by language, distance, and local law. To facilitate trade and interaction a common set of commercial 'rules' was needed.").

28. Id.

29. Id.; see also Larry J. Pittman, The Federal Arbitration Act: The Supreme Court's Erroneous Statutory Interpretation, Stare Decisis, and a Proposal for Change, 53 ALA. L. REV. 789, 793 (2002) (attributing the continued practice of arbitration in England since the medieval period to the "need for a speedy and efficient dispute resolution mechanism as ... 
chose arbitrators who could facilitate efficient adjudication of disputes and account for cultural differences with foreign traders. ${ }^{30}$

For centuries, arbitration remained the primary method for resolving commercial disputes in England. ${ }^{31}$ Eventually, however, English common law judges became hostile toward arbitration, fearing that its continued use would weaken the English court system. ${ }^{32}$ Accordingly, it became routine for judges to avoid enforcing arbitration clauses in contracts. ${ }^{33}$

\section{B. Early American Arbitration and the Passage of the Federal Arbitration Act}

The English judicial hostility to arbitration agreements crept into the

[merchants] traded ... . in foreign markets”).

30. Id. at 793. Interestingly, the early popularity of arbitration formed somewhat out of market distrust of state-sponsored methods for dispute resolution. See Leeson, supra note 25, at 31-32 (responding to critics who suggest otherwise). Professor Leeson writes:

In the 20th century private international arbitration associations sprung up. Arbitration associations operate much like the medieval merchant courts discussed above. These organizations emerged in response to the demands of international traders who viewed state courts as inferior mechanisms of dispute resolution. State courts posed a number of practical problems for resolving international commercial disagreements. Competing jurisdictional claims between states was one issue. The refusal of some nations' courts to adjudicate international commercial contracts was another.

Id.

31. See Sarah Rudolph Cole, Incentives and Arbitration: The Case Against Enforcement of Executory Arbitration Agreements Between Employers and Employees, 64 UMKC L. REV. 449, 461 (1996) (noting the primacy of arbitration throughout the seventeenth and eighteenth centuries).

32. See id. ("Eventually, however, common law judges became concerned that the merchants' ability to systematically circumvent common law court procedures by agreeing to submit their disputes to arbitration had resulted in a reduction of the judges' salaries.” (citing Kill v. Hollister, 1 Wils. 129, 95 Eng. Rep. 532 (1746))).

33. Professor Cole suggests, " $[\mathrm{t}] \mathrm{o}$ avoid losing fees to arbitrators, common law judges developed what came to be known as the 'ouster doctrine.' Allegedly originating in the seventeenth century, judges used the ouster doctrine to invalidate executory agreements to arbitrate in a series of cases during the eighteenth century." Id. at 462 . Although most disputes submitted to arbitration during this time were commercial in nature, courts often found ways around enforcing arbitration clauses. See Jeffery W. Stempel, Pitfalls of Public Policy: The Case of Arbitration Agreements, 22 ST. MARY's L.J. 259, 272 (1990) ("In some English cases, the courts found predispute arbitration agreements voidable at the option of either party. In other cases, probably the majority, the courts viewed the arbitration agreement, particularly if it was evidenced by a signed writing, as a legitimate contract, but one that was not specifically enforceable.”).

The doctrine of revocability was another mechanism used by the courts to circumvent enforcing arbitration clauses. See Earl S. Wolaver, The Historical Backgrounds of Commercial Arbitration, 83 U. PA. L. REV. 132, 138 (1934) (tracing the doctrine of revocability to dictum by Lord Coke in Vynior's Case, 8 Co. 80a, 81b, (1609)). 
early colonies that became the United States, ${ }^{34}$ but as the country grew, merchants increasingly turned to arbitration to adjudicate commercial disputes. $^{35}$ Thus, the business community eventually sought to reverse the residual judicial hostility, ${ }^{36}$ and looked to Congress for a solution. ${ }^{37}$ Congress answered with the passage of the FAA.

The original draft of what would ultimately become the FAA was enacted in $1925,{ }^{38}$ principally to address the problems of judicial hostility toward arbitration in the United States court system. ${ }^{39}$ Despite initial questions on the federal exclusivity of arbitration, ${ }^{40}$ the Supreme Court eventually interpreted the FAA to preempt state law limiting the ability of parties to submit their claims to arbitration at variance with the FAA. ${ }^{41}$ Still, state law plays a very important role in federal arbitration jurisprudence with respect to providing guidance as to whether a contract

34. See Stempel, supra note 33, at 274 (discussing the early development of American arbitration).

35. Id. at 275. See also William C. Jones, An Inquiry Into the History of the Adjudication of Mercantile Disputes in Great Britain and the United States, 25 U. CHI. L. REV. 445, 461-62 (1958) ("Statistics are not available and it is doubtful that they ever will be, but it is probable that in the nineteenth century arbitration in one form or another became the most important form of mercantile dispute settlement . . . in the United States . . . although courts continued, of course, to be used.”).

36. See Atlantic Fruit Co. v. Red Cross Line, 276 F. 319, 322 (S.D.N.Y. 1921) (recognizing the general displeasure in the business community with courts' unwillingness to enforce arbitration agreements in the early twentieth century). This view, however, was not uniform, and many courts began to take individual notice of the need for a jurisprudence favoring arbitration, even though a national policy favoring arbitration had not yet been made official. See e.g., Berkovitz v. Arbib \& Houlberg, Inc., 130 N.E. 288, 290-92 (N.Y. 1921) (Cardozo, J.) (recognizing the importance of arbitration agreements, but noting common law limitations on enforcement).

37. H.R. REP. No. 96, at 1-2 (1924).

38. 43 Stat. 883 (1925) (current version at 9 U.S.C. §§ 1-16 (2006)).

39. The original act was not initially known as the FAA; it was known as the United States Federal Arbitration Act ("USAA"). IAN R. MACNEIL, AMERICAN ARBITRATION LAW 102-15 (1992). The American Bar Association (“ABA”), following a series of legislative exchanges with Congress, ultimately submitted a bill in 1923, which Congress enacted without much change. See generally id. at 102 (providing a more in-depth discussion about the legislative history of the FAA).

40. Erie R. R. v. Tompkins, 304 U.S. 64, 78 (1938), overruled Swift v. Tyson, 41 U.S. 1 (1842), on the ground that it is unconstitutional to permit federal courts to ignore state autonomy by applying federal substantive common law, and thus held that federal district courts are required to apply state substantive law in diversity cases. The Court later applied the basic Erie principle to require the application of state arbitration law in 1956, creating obvious conflicts with the substantive provisions of the FAA. See MACNEIL, supra note 39, at 136, 169 (citing Bernhardt v. Polygraphic Co. of Am., 350 U.S. 198 (1956)).

41. See Southland Corp. v. Keating, 465 U.S. 1, 10-16 (1984) (holding that the FAA preempts state law limiting the enforcement of arbitration agreements); cf. Kenneth F. Dunham, 6 PePp. Disp. Resol. L.J. 197, 199 (2006) (discussing alternative views on the implications of Southland). 
containing an arbitration clause is valid in the first instance. ${ }^{42}$

\section{The Basic Structure of the FAA and the General Right to Stay Litigation and Compel Arbitration Pursuant to a Valid Contract}

The FAA — codified at Title 9 of the United States Code ${ }^{43}$ — provides a federal mechanism for the recognition of agreements to arbitrate claims. ${ }^{44}$ The Act has a domestic portion, ${ }^{45}$ and codifies two international arbitration treaties: The Convention on the Recognition and Enforcement of Arbitral Awards ("The New York Convention"), ${ }^{46}$ and the Inter-American Convention on International Commercial Arbitration. ${ }^{47}$ This article focuses on the domestic sections dealing with parties' ability to compel arbitration and stay litigation pursuant to otherwise valid agreements. ${ }^{48}$

The first of these sections, 9 U.S.C. $\S 3$, provides in pertinent part:

If any suit or proceeding be brought in any of the courts of the United States upon any issue referable to arbitration under an agreement in writing for such arbitration, the court in which such suit is pending, upon being satisfied that the issue involved in such or proceeding is referable to arbitration under . . . [the] agreement, shall on application of one of the parties stay the trial of the action until such arbitration . . . [occurs]. ${ }^{49}$

Thus, $\S 3$ provides the statutory authority for district courts to stay trials pending arbitration in cases for which federal subject matter jurisdiction already exists. ${ }^{50}$ Section 4 provides:

A party aggrieved by the alleged failure, neglect, or refusal of

42. Note, An Unnecessary Choice of Law: Volt, Mastrobuono, and Federal Arbitration Act Preeemption, 115 Harv. L. Rev. 2250, 2253 (2002) (discussing the extent of federal preemption of state arbitration law); see also Christopher R. Drahozal, In Defense of Southland: Reexamining the Legislative History of the Federal Arbitration Act, 78 NotRE DAmE L. ReV. 101, 112 (2002) (discussing the Southland Court's examination of the legislative history of the FAA in the latter regard).

43. 9 U.S.C. $\S \S 1-16$.

44. Id. § 2 ("A written provision . . . evidencing a transaction involving commerce to settle by arbitration a controversy ... . shall be valid, irrevocable, and enforceable, save upon such grounds as exist at law or in equity for the revocation of any contract.”).

45. Id. §§ 1-16.

46. Id. $\S \S 201-08$.

47. Id. $\S \S 301-07$.

48. Whether the domestic sections of the act apply concomitantly with the foreign provisions can be significant in many contexts. See GARY B. BORn, InTERNATIONAL COMMERCIAL ARBITRATION IN THE UNITED STATES 464 (1994) (discussing the various views and interpretative problems on the application of the domestic provisions of the FAA to the international provisions).

49. 9 U.S.C. $\S 3$ (emphasis added).

50. Id. 
another to arbitrate under a written agreement for arbitration may petition any United States district court which, save for such agreement, would have jurisdiction . . . of the subject matter of a suit arising out of the controversy between the parties, for an order directing that such arbitration proceed in the manner provided for in such agreement. ${ }^{51}$

This section establishes a mechanism for a litigant to petition the district court for an order to compel arbitration when an opposing party who has previously agreed to arbitrate claims under an agreement suddenly refuses to do so. ${ }^{52}$ The litigant must present another basis for federal subject matter jurisdiction before the court may compel arbitration ${ }^{53}$ again, at least with respect to domestic actions. ${ }^{54}$

Thus, $\S \S 3$ and 4 are the primary vehicles both to stay proceedings pending arbitration and to compel arbitration when necessary. ${ }^{55}$ In addition, the FAA provides for an interlocutory appeal of the refusal to grant a stay under $\S 3$ and a denial of a petition under $\S 4 .^{56}$

Section 16, which deals with such appeals under $\S \S 3$ and 4, provides in pertinent part:

(a) An appeal may be taken from-

(1) an order-

(A) refusing a stay of any action under section 3 of this title,

(B) denying a petition under section 4 of this title. $^{57}$

Accordingly, assuming that a valid contract exists, a denial of a

51. 9 U.S.C. $\S 4$ (emphasis added).

52. Id.

53. Id.

54. Cf. Chromalloy Aeroservices v. Egyptian Arab Republic, 939 F. Supp. 907 (D.D.C. 1996) (finding subject matter jurisdiction to hear a case to enforce an award rendered in another country - on grounds other than under the New York Convention-in order to illustrate the availability of a right to enforcement under U.S. arbitration law). As an interesting caveat, the Chromalloy decision has been heavily criticized by many scholars. See, e.g., William W. Park, Duty and Discretion in International Arbitration, 93 AM. J. INT'L. L. 805, 807 (1999) (noting that the court reached this conclusion "[i]n an opinion [supported by] neither precedent nor progeny”).

55. 9 U.S.C. $\S \S 3,4$.

56. Id. § 16 .

57. Id. 
motion to stay litigation or to compel arbitration may be appealed immediately. ${ }^{58}$ Most importantly, the ability to compel or to request a stay appears to call for the existence of a contract containing an agreement to arbitrate disputes. As this article illustrates, concluding from these sections that Congress did not intend to place a limiting gloss on state substantive contract law by imposing a requirement that there be a written agreement between parties before a litigant may avail itself of these provisions leads to a result that is potentially problematic from a policy perspective, ${ }^{59}$ and constitutionally deficient.

\section{The Seventh Amendment Right to Jury Trial}

"The Seventh Amendment preserves to litigants the right to jury trial in suits at common law." ${ }^{\prime 0}$ The Supreme Court has set forth further rules explaining the meaning of the Seventh Amendment and providing a context for understanding when a litigant is to be afforded the right to trial by jury. ${ }^{61}$ Specifically, courts are to apply a "historical test," ascertaining whether the parties to a cause of action would have had the right to have their claims tried by a jury in England in 1791-the time at which the Seventh Amendment was adopted. ${ }^{62}$ Generally, if a party's claim involves an action at law-meaning that it could have been brought in a court with legal jurisdiction at the common law ${ }^{63}$ — a jury must be afforded if properly

58. Id. Section 16 provides a statutory exception to the final judgment rule, 28 U.S.C. § 1291. The final judgment rule provides that appeals from district court rulings generally can be taken only if the district court has rendered final decisions on the issues presented below. 28 U.S.C. § 1291; see also Adam N. Steinman, Reinventing Appellate Jurisdiction, 48 B.C. L. REV. 1237, 1247-70 (2007) (discussing other well-recognized exceptions to the final judgment rule).

59. See Arthur Andersen, L.L.P. v. Carlisle, 129 S. Ct. 1896, 1093-94 (2009) (Souter, J., dissenting) (noting the policy problems presented by permitting nonsignatories to avail themselves of arbitration clauses in order to obtain stays of litigation under § 3).

60. Ross v. Bernhard, 396 U.S. 531, 533 (1970); see also U.S. CONST. amend. VII (guaranteeing the right to trial by jury in suits at common law when the value in controversy exceeds a minimum value of twenty dollars).

61. See Beacon Theatres v. Westover, 359 U.S. 500 (1959) (holding that legal claims must be tried to a jury before any equitable claims with overlapping issues of fact can be decided). The Court has further held that equitable issues must be tried after legal issues even if they are only incidental to the equitable issues. Dairy Queen, Inc. v. Wood, 369 U.S. 469, 473-74 (1962).

62. Dimick v. Schiedt, 293 U.S. 474, 476 (1935); see also Margaret L. Moses, What the Jury Must Hear: The Supreme Court's Evolving Seventh Amendment Jurisprudence, 68 GeO. WASH. L. REV. 183, 199 (2000) ("The historical test is one means of determining whether parties to a particular action have the right to a jury trial.”).

63. See Parsons v. Bedford, 28 U.S. 433, 446 (1830) (finding that the Seventh Amendment preserves the right to a jury trial for suits in "law" within the meaning of Article III). 
requested. ${ }^{64}$ The overarching common law distinction between law and equity has been replaced, however, as there is now only one form of action permitted in the federal courts under the Federal Rules of Civil Procedure: a civil action. ${ }^{65}$ Moreover, the analysis becomes more complicated if the claim is for an action that did not exist at the common law, neither as an equitable nor legal claim. ${ }^{66}$

In Ross v. Bernhard, the Supreme Court developed a three-pronged test to ascertain whether the right to trial by jury exists in cases that present neither clearly legal nor clearly equitable claims. ${ }^{67}$ Specifically, the Court stated, "[a]s our cases indicate, the 'legal' nature of an issue is determined by considering, first, the pre-merger custom with reference to such questions; second, the remedy sought; and, third, the practical abilities and limitations of juries."

The extent to which the right to a jury trial is implicated at all in the following discussion, then, depends on whether a right to a jury trial exists in the first instance. This article will not analyze numerous distinctive fact patterns in order to determine whether the right to trial by jury should be available in any one particular case; it suggests only that where a party's claims are able to be submitted to a jury, they should be, and a nonsignatory should not be able to subvert that result by utilizing an arbitration clause under a misapplication of equitable estoppel.

In undertaking this analysis, one must keep in mind that Federal Rule of Civil Procedure 38(b) provides that a party "waives [the right to] a jury trial" unless he complies with the demands of the rule. ${ }^{69}$ This latter aspect has substantial implication regarding the voluntariness of arbitration agreements in general, because if a party has signed an agreement to arbitrate claims, the argument ostensibly may be advanced that the right to trial by jury is waived as a result. ${ }^{70}$

\section{A DISCUSSION}

\section{A. How the Federal Pro-Arbitration Policy Sometimes Usurps the Right to}

64. FED. R. CIV. P. 38(b) (requiring that a party requesting a jury trial must make proper demand).

65. FED. R. Civ. P. 2 ("There is one form of action-the civil action.”).

66. See Moses, supra note 62, at 197-99 (showing the Justices' divergent views on the importance of finding historical analogues to current causes of action in ascertaining the right to a jury trial).

67. 396 U.S. 531 (1970).

68. Id. at $538 \mathrm{n} .10$. The third prong articulated in Ross was altered in subsequent cases. See Moses, supra note 62, at 197 (providing more information on Ross and its progeny).

69. FED. R. Civ. P. 38(b). Failure to make demand amounts to waiver. Id.

70. See infra, Section III.C (discussing waiver issues in greater detail). 
Trial by Jury

Because the FAA provides that ordinary common law contract principles still govern questions as to whether an agreement to arbitrate is actually valid, ${ }^{71}$ the result in cases where a party loses the right to a jury trial pursuant to an arbitration clause invoked by a nonsignatory under a traditional state contract theory may seem at first blush to accord with the Act's mandates. As noted in the section below, the Supreme Court, at least implicitly, agreed with this proposition in Carlisle.

\section{Carlisle and Its Potential Implications}

In May of 2009, the Supreme Court decided the case of Arthur Andersen, L.L.P. v. Carlisle. ${ }^{72}$ In this case, the Court was faced with two questions: (1) whether $\S 16$ of the FAA vests federal courts with interlocutory appellate jurisdiction over denials of motions to stay under $\S$ 3 filed by nonsignatories to arbitration agreements; and (2) whether nonsignatories can obtain stays of litigation under the FAA in any event. ${ }^{73}$

In Carlisle, the three respondents sold their construction company seeking to minimize tax liability from the sale. ${ }^{74}$ Through a series of consultations with their tax advisor, Arthur Andersen, L.L.P., they were referred to two other firms for legal advice on the transaction. ${ }^{75}$ These firms recommended that the respondents implement a "'leveraged option strategy' tax shelter designed to create illusory losses through foreigncurrency-exchange options."76 Further, in line with the advice, the respondents created various limited liability corporations to carry out the

71. See 9 U.S.C. § 2.

72. 129 S. Ct. 1896 (2009).

73. Id. at 1896-99. The Supreme Court granted certiorari on these issues, see Carlisle v. Curtis, Mallet-Prevost, Colt \& Mosle, L.L.P., 521 F.3d 597 (6th Cir. 2008), cert granted, Arthur Andersen L.L.P. v. Carlisle, 129 S. Ct. 529 (2008), to resolve confusion among circuits. Compare Ross v. Am. Express Co., 478 F.3d 96, 100 (2d Cir. 2007) (holding that nonsignatories can compel arbitration under the doctrine of equitable estoppel and that the court had jurisdiction to hear appeals of denials of motions to compel pursuant to that theory), with DSMC Inc. v. Convera Corp., 349 F.3d 679, 680-83 (D.C. Cir. 2003) (holding that $\S 16(\mathrm{a})(1)(\mathrm{A})$ or (B) is insufficient to give appellate jurisdiction to a nonsignatory's attempt to compel arbitration pursuant to the doctrine of equitable estoppel). One court previously attempted to reconcile the differences between opinions of different courts in cases implicating the international provisions of the FAA. See Sourcing Unlimited, Inc. v. Asimco Int'l, Inc., 526 F.3d 38 (1st Cir. 2008) (holding that nonsignatories should be permitted to compel arbitration under 9 U.S.C. $\S 206$ and that nothing in the statutory language suggests there is any limitation on this right-or the right to appeal denials of a motion to compel).

74. Carlisle, 129 S. Ct. at 1899.

75. Id.

76. Id. 
scheme, and these corporations "entered into investment-management agreements with [one of the firms,]" which required all disputes arising out of the agreements to be submitted to arbitration. ${ }^{77}$ The IRS later determined the scheme to be an illegal tax shelter, and the respondents subsequently filed a diversity suit against all of the firms under the agreements for rendering flawed and fraudulent advice. ${ }^{78}$

The defendant-firms that were not signatories to the underlying investment-management agreements moved to stay the action under $\S 3$ of the FAA, "arguing that the principles of equitable estoppel demanded that respondents arbitrate their claims under the investment agreements."79 The district court denied the motion, and the nonsignatory firms appealed. ${ }^{80}$ The Sixth Circuit held that it did not have appellate jurisdiction to hear the appeal under $\S 16(a)(1)$ of the FAA because that section only makes reviewable the denial of a motion under $\S 3$, and $\S 3$ requires the existence of a written agreement between the parties who wish to arbitrate, which was ostensibly absent in the case. ${ }^{81}$

The Supreme Court reversed the Sixth Circuit on the jurisdictional question. ${ }^{82}$ Writing for the majority, Justice Scalia noted that "[ $\left[\begin{array}{l}16\end{array}\right]$ unambiguously makes the underlying merits [of an appeal] irrelevant, for even utter frivolousness of the underlying request for a $\S 3$ stay cannot turn a denial into something other than 'an order . . . refusing a stay of any action under section 3.", 83 Thus, the Court held that "any litigant who asks for [and is denied] a stay . . . is entitled to an immediate appeal." ${ }^{\text {, }}$

But Justice Scalia did not stop at holding that lower courts should not conflate the jurisdictional question under $\S 16$ with the underlying merits question - that is, whether a litigant is entitled to invoke an arbitration clause-but he continued to address the Court of Appeals' "ground for finding [the] appeal meritless[.]" pro-arbitration mantra that the Court has systematically repeated in the past. $^{86}$ The Court reasoned that, because $\S 2$ of the FAA "creates substantive federal law regarding the enforceability of arbitration

77. Id.

78. Id.

79. Carlisle, 129 S. Ct. at 1900.

80. Id.

81. Carlisle v. Curtis, Mallet-Prevost, Colt \& Mosle, LLP, 521 F.3d 597, 600 (6th Cir. 2008).

82. Carlisle, 129 S. Ct. at 1900.

83. Id. at 1901 (quoting 9 U.S.C. $\S 16$ ).

84. Id. at 1900.

85. Id. at 1901 (noting that "if the Court of Appeals is correct on the merits point we will have awarded petitioners a remarkably hollow victory.”).

86. Id. (stating that arbitration agreements should be placed on equal footing with other contracts (quoting Volt Info. Sci., Inc. v. Bd. of Tr. of Leland Stanford Junior Univ., 489 U.S. 468, 478 (1989))). 
agreements," it does not purport to "alter background principles of state contract law regarding the scope of agreements[.]" ${ }^{87}$ And, as a logical subsequent inference, categorically mandating the existence of a written agreement to invoke $\S 3$-and by extension, $\S 16$-ignores the fact that, under traditional state contract law, nonparties can enforce contracts. ${ }^{88}$

The result broadens the scope of access to arbitration agreements and is part and parcel with the federal pro-arbitration policy. ${ }^{89}$ That is, by attempting to craft a narrow holding on the scope of appellate jurisdiction under $\S 16$, and by ignoring the apparent textual mandate of a written agreement between parties under $\S 3$, Justice Scalia has implicitly sanctioned the ability of federal courts to allow nonsignatories to arbitration agreements the option of staying litigation and compelling arbitration under a potential surfeit of theories that unfairly may usurp the jury trial right.

Justice Souter, writing for the dissent in Carlisle, noted the problem of permitting nonsignatories to invoke $\S 3$, but under different reasoning. Specifically, he wrote that, because of the federal policy disfavoring interlocutory appeals, $\S 3$ should be read to impose a federal requirement that a written agreement exist before a party may be permitted to stay court proceedings pending arbitration. ${ }^{90}$ This independent limitation seems to be reasonable given that $\S 3$ textually permits a court to grant stays only where there is "an agreement in writing," compel arbitration only under "a written agreement." stated, this requirement would "provid[e] a bright-line rule with predictable results to aid courts in determining jurisdiction over $\S 16$ interlocutory appeals ... . [and] mitigat[e] the risk of intentional delay by savvy parties who seek to frustrate litigation by gaming the system." 93 More importantly for the purposes of this article, however, the requirement would also eliminate the ability of courts to eradicate a signatory-party's right to jury trial and access to the court system for the mere sake of efficiency and the federal pro-arbitration policy.

Again, it must be acknowledged that Justice Scalia attempted to narrow the Court's holding by stating that "we need not decide here whether the relevant state contract law recognizes equitable estoppel as a

87. Carlisle, 129 S. Ct. at 1901-02.

88. Id. at 1902 (noting that such nonparties can enforce an agreement under doctrines such as " "assumption, piercing the corporate veil, alter ego, incorporation by reference, third-party beneficiary theories, waiver and estoppel[.]”” (quoting 21 SAMUEL WiLliston \& Richard A. LORD, A TREATISE ON THE LAW OF CONTRACTS § 57.19 (4th ed. 2001))).

89. Id.

90. Carlisle, 129 S. Ct. at 1903-04 (Souter, J., dissenting).

91. 9 U.S.C. $\S 3$.

92. Id. § 4.

93. Carlisle, 129 S. Ct. at 1904 (Souter, J., dissenting). 
ground for enforcing contracts against third parties, what standard it would apply, and whether petitioners would be entitled to relief under it." ${ }^{94}$ Yet, by refusing to categorically exempt third parties from enforcing arbitration clauses under $\S 3$, he has given courts a carte blanche to disregard litigants' right of access to the courts. To illustrate this proposition, this article uses only the application of equitable estoppel by many circuits - a doctrine under which courts often do not determine whether an arbitration clause is valid, but inquire only as to whether a nonsignatory can avail itself of the clause-as a prime example. This application lends to a remarkably unfair result not supported by an application of true common law equitable estoppel. $^{95}$ It permits the plaintiffs, in the mentioned cases, to lose completely the right to have their legal claims heard by a jury and gives appellate courts the opportunity to review such denials, vesting another judicial body with the capacity to usurp the traditional jury function. ${ }^{96}$ However, how the jury trial right is implicated in these cases must first be discussed.

\section{How the Right to Jury Trial is Implicated in Equitable Estoppel Cases}

Perhaps the ultimate result in Carlisle is supported by the federal policy preferring arbitration to litigation in most circumstances. ${ }^{97}$ It may even be argued that it promotes efficiency in many respects because most cases presenting this issue involve a plaintiff asserting claims against numerous defendants - claims that involve many overlapping issues of law and fact. But this policy preference of efficiency should not come at the expense of constitutional rights and fairness to litigants who have little means of otherwise altering their conduct in order to avoid having a nonsignatory avail itself of an arbitration clause.

In the spirit of this argument, Professor Sternlight has shown that practitioners and courts have largely ignored various constitutional violations presented by the federal policy favoring binding arbitration. ${ }^{98}$ As

94. Id. at 1903.

95. See infra Section II.B. (suggesting that this happens because, in such cases, the courts do not apply the rules of traditional estoppel and do not require a minimal showing of misrepresentation and detrimental reliance).

96. See infra Section II.B. (stating that when the court allows a nonsignatory defendant to compel arbitration, the plaintiff loses his right to a jury trial).

97. See Ross v. Am. Express Co., 478 F.3d 96, 99 (2d Cir. 2007) (noting that permitting nonsignatories to avail themselves of arbitration clauses under the theory of equitable estoppel accords with the federal pro-arbitration policy and avoids "unnecessary complexities in cases involving arbitration agreements").

98. See supra note 15 and accompanying text (recognizing that the federal preference for arbitration often denies plaintiffs of their right to trial by jury). As an interesting 
mentioned below in Section III.C., she notably contends that, because traditional waiver standards required for the relinquishment of the jury trial right are not even considered by most courts, many arbitration agreements simply usurp the right without any contemplation of the collateral effects. ${ }^{99}$ This is particularly true when arbitration clauses are unfairly imposed. ${ }^{100}$

Indeed, it must be acknowledged that a jury can provide the benefit of a neutral-and perhaps sympathetic-factfinder in cases where an opposing party has much greater resources. ${ }^{101}$ However, the fact that a jury

corollary on efficiency considerations, one commentator has similarly suggested that courts sometimes ignore the requirements of the Seventh Amendment in the dispositive motion context. See Craig M. Reiser, Comment, The Unconstitutional Application of Summary Judgment in Factually Intensive Inquiries, 12 U. PA. J. Const. L. 195, 221 (2009) ("[P]rinciples of judicial economy make it easy to comprehend why there may be a proclivity to enter docket-clearing summary judgment grants in weak jury cases . . . [but] compromising constitutional rights for efficiency's sake is an unconstitutional solution.”).

99. Id.

100. Jean R. Sternlight, The Rise and Spread of Mandatory Arbitration as a Substitute for the Jury Trial, 38 U.S.F. L. REV. 17, 22 (2003); see also Jean R. Sternlight \& Elizabeth J. Jensen, Using Arbitration to Eliminate Consumer Class Actions: Efficient Business Practice or Unconscionable Abuse?, 67 LAW \& CONTEMP. PROBS. 75, 102 n. 167 (2004) (recognizing that unconscionable arbitration clauses prevent the law from being properly enforced). Professor Sternlight notes that "[a]lthough one of the most significant aspects of mandatory arbitration is that it denies claimants access to court or to a jury trial, lawyers, courts, and policy makers have typically failed to pay sufficient attention to jury trial guarantees.” Sternlight, supra, at 20. Professor Sternlight discusses the willingness of some state courts to address the obvious implication of a litigant potentially losing the right to trial by jury pursuant to a mandatory arbitration clause. See id. at 21 (citing Kloss v. Edward D. Jones \& Co., 54 P.3d 1 (Mont. 2002) (Nelson, J., concurring) (discussing the holding of the case where a litigant did not waive her Montana right to trial by jury by signing an agreement to arbitrate because voluntariness was not shown)). Interestingly, she also discusses how other state courts are unwilling to address this problem. See id. at 32 (citing Graham v. State Farm Mut. Auto. Ins. Co., 565 A.2d 908 (Del. 1989) (upholding an agreement to arbitrate despite the plaintiff's lack of knowledge as to the existence of an arbitration clause in the contract)).

101. The Supreme Court has also offered the following rationale in favor of a jury: "Twelve men of the average of the community ... know more of the common affairs of life than does one man, [and it is assumed] that they can draw wiser and safer conclusions from admitted facts thus occurring than can a single judge.” R.R. Co. v. Stout, 84 U.S. 657, 664 (1873).

However, overly extolling the virtues of a jury trial may unfairly devalue the benefit arbitration provides to litigants - particularly businesses-who desire quicker and more efficient dispute resolution. See Murray S. Levin, The Role of Substantive Law in Business Arbitration and the Importance of Volition, 35 AM. Bus. L.J. 105, 106 (1997) (stating that "[a]rbitration is intended to provide a quicker, less expensive, and more private alternative to litigation”).

Further, this article does not purport to suggest that juries may be superior in all respects to experts in adjudicating complicated disputes. The Supreme Court has recognized this aspect, for example, by holding that the construction questions on patents are to be made by judges. Markman v. Westview Instruments, Inc., 517 U.S. 370, 379-81 (1996) (noting the limitations of juries). 
trial is a constitutional right in the first instance cannot be refuted. ${ }^{102}$ The Supreme Court has itself recognized that arbitration should not be a matter of coercion in stripping litigants of their right of access to the courts, ${ }^{103}$ and it has further suggested that the FAA “ "does not require parties to arbitrate when they have not agreed to do so." "104 As this article attempts to show, in cases where a nonsignatory is permitted to compel arbitration under a misapplication of traditional equitable estoppel, what occurs in substance is that a litigant who was not an actual or anticipated party to the agreement can bind another who was, preventing her from receiving her day in court before a jury. ${ }^{105}$

Furthermore, although the FAA makes arbitration clauses enforceable on the basis of state law-as expressed in Carlisle under $\S 2^{106}$ - it seems unlikely that Congress originally intended that this substantive provision would permit federal courts to adopt a rule allowing a nonsignatory to unfairly submit another party to arbitration pursuant to a flawed theory. This is evidenced by the seemingly independent requirement of a written agreement stated in $\S \S 3$ and 4, a limitation that Justice Scalia rejected. ${ }^{107}$ In that vein, the following section discusses just how various federal courts both frequently and unfairly misapply equitable estoppel.

\section{B. Misapplying Equitable Estoppel}

Carlisle's implicit sanction of the application of equitable estoppel adopted by many circuits is but one of the potential encompassing effects of the Court's decision to keep the door open for nonsignatory third parties to utilize arbitration agreements at the expense of litigants' jury trial rights. In that vein, Frank LaForge's argument illustrates the problems with equitable estoppel as it is applied by courts in this context. ${ }^{108}$ Namely, he

102. See supra Section II.C. (recognizing that there is a constitutional right to trial by jury).

103. See EEOC v. Waffle House, Inc., 534 U.S. 279, 294 (2002) (noting that “"[a]rbitration under the [FAA]'” should be "“a matter of consent, not coercion"” (quoting Volt Info. Sci., Inc. v. Bd. of Trustees of Leland Stanford Junior Univ., 489 U.S. 468, 479 (1989))).

104. Id. at 293 (quoting Volt Info. Sci., Inc., 489 U.S. at 478 (1989)).

105. See infra note 108 and accompanying text (describing how traditional equitable estoppel doctrine is often misapplied in these cases).

106. See 9 U.S.C. $\S 2$ (noting that written agreements to settle controversies by arbitration are valid and enforceable).

107. Arthur Andersen, L.L.P. v. Carlisle, 129 S. Ct. 1896, 1899-2002 (2009).

108. LaForge, supra note 4. LaForge uses the case of Grigson v. Creative Artists Agency, L.L.C., 210 F.3d 524 (5th Cir. 2000), to illustrate the common factual presentation in cases where nonsignatories seek to compel arbitration. See Laforge, supra, at 232 (noting that Grigson is one of the "two most important cases regarding the use of equitable estoppel to compel signatories to arbitrate with nonsignatories”). In Grigson, two producers of a 
suggests-first noting the obvious quandary with the typical case in that a plaintiff and a nonsignatory defendant do not actually agree to arbitratethat courts applying equitable estoppel in these cases effectively confuse the actual parties at controversy and neglect to apply the misrepresentation and detrimental reliance requirements of traditional estoppel. ${ }^{109}$ That is, these courts view the nonsignatory defendant as entering into a hypothetical agreement to arbitrate claims with the plaintiff, regardless of whether the plaintiff could have had any reasonable means of anticipating such a result. But this view ostensibly distorts the traditional equitable estoppel doctrine, which requires a minimal showing of misrepresentation and detrimental reliance. ${ }^{110}$ In essence, the approach obfuscates traditional contract law, and leads to uncertainty and unfairness. ${ }^{111}$

Moreover, in a case where a nonsignatory can compel arbitration or stay litigation under this application of equitable estoppel, courts do not necessarily look at the actions or conduct of the plaintiff who initiates the litigation; they look only at the face of the plaintiff's claims against a signatory-defendant in order to ascertain whether there are overlapping issues with claims filed against a nonsignatory-defendant. ${ }^{112}$ This in turn

horror movie sued the movie's distribution company, alleging that the company failed to distribute the movie as originally agreed upon. See id. at 234 (citing Grigson, 210 F.3d at 526). The producers also sued the agency of one of the stars of the movie for allegedly interfering with the movie's distribution and aiding the breach. See id. at 234-35 (noting that the defendants joined Grigson in another suit against Creative Artists and Matthew McConaughey for tortious interference with the distribution agreement). The agency sought to enforce an arbitration clause contained in the agreement between the distribution company and the plaintiff-producers on the grounds that the plaintiff-producers were equitably estopped from refusing to arbitrate all claims arising from the distribution agreement. Id.

In addition, as LaForge demonstrates, the presumption in most of these cases - even if it is unreasonable-is that the plaintiff will attempt to hold a nonsignatory-defendant liable under duties imposed by an underlying agreement, and as such, the nonsignatory-defendant should be permitted to avail himself of the arbitration provisions in that agreement. Id. at 231-39.

109. Id. at 242-44.

110. Id. at 245 (citing 12 SAmuel Williston \& Richard A. LoRD, A TrEatise ON THE LAW OF CONTRACTS $\S 8: 3$ (4th ed.)). This definition of the traditional showing of estoppel has been articulated by the Supreme Court in Heckler v. Community Health Services of Crawford County, Inc., 467 U.S. 51, 61 (1984), where the Court noted that "[t]o analyze the nature of a . . . party's detrimental change in position, we must identify the manner in which reliance on the [other party's] misconduct has caused [him] to change his position for the worse." Other sources specify these requirements as well. See, e.g., Restatement (SECOND) AGENCY § 8B (1957) (suggesting that estoppel prevents a party from insisting on the truth of a statement contrary to a representation made upon which another party detrimentally relied).

111. See infra Section III.C. (discussing the negative impact this practice can have on the plaintiff's rights).

112. See LaForge, supra note 4, at 249-50 (describing how this practice does not follow traditional estoppel doctrine). 
may necessitate that the case against the nonsignatory be tried in arbitration. ${ }^{113}$ And again, these courts fail to consider whether the plaintiff in fact made any misrepresentation upon which the nonsignatory defendant detrimentally relied. ${ }^{114}$

The quintessential case demonstrating the latter application of equitable estoppel is MS Dealer Services Corp. v. Franklin. ${ }^{115}$ In that case, the Eleventh Circuit specified two separate circumstances under which a nonsignatory can compel arbitration: first, where the signatory's claims against the nonsignatory presume the existence of an underlying written agreement to arbitrate or rely on the affirmative provisions of such an agreement; and second, where the signatory's claims " "raise[] allegations of . . . substantially interdependent and concerted misconduct by both the nonsignatory and one or more of the signatories to the contract.',116

In MS Dealer, the plaintiff executed a buyer's order to purchase a vehicle from an automobile dealership. ${ }^{117}$ As part of that order, she was charged for a third-party service contract with MS Dealer, a nonsignatory to the underlying agreement. ${ }^{118}$ The buyer's order contained an arbitration clause which provided that "'all disputes and controversies of every kind and nature between the parties ... a arising out of or in connection with this contract . . . shall be submitted to binding arbitration[.]","119 Shortly after the purchase of the car, the plaintiff discovered numerous defects in it, and filed suit against the dealership and MS Dealer, stating claims for fraud, breach of contract, conspiracy, and breach of warranty. ${ }^{120}$ Subsequently, MS Dealer sought to invoke the arbitration clause by compelling the plaintiff to arbitrate her claims against it on the theory of equitable estoppel. ${ }^{121}$ The district court denied the motion because MS Dealer was not a signatory to the buyer's order and accordingly did not have legal standing to compel arbitration. ${ }^{122}$

The Eleventh Circuit reversed the district court, holding that both prongs of its test were satisfied. ${ }^{123}$ In particular, each of the plaintiff's claims against MS Dealer made reference to and presumed the existence of the third-party service agreement, which was incorporated into the buyer's

113. Id.

114. Id.

115. MS Dealer Serv. Corp. v. Franklin, 177 F.3d 942 (11th Cir. 1999) (“MS Dealer”).

116. Id. at 947 (quoting Boyd v. Homes of Legend, Inc., 981 F. Supp. 1423, 1433 (M.D. Ala. 1997)).

117. Id. at 944 .

118. Id.

119. Id. (citing Buyer's Order at 1 ).

120. MS Dealer, 177 F.3d at 944.

121. Id. at 945 .

122. Id.

123. Id. at 947. 
order. $^{124}$ However, more problematically, the court also held that the plaintiff's claims against both the automobile dealer and MS Dealer were based on the same facts and were therefore "inherently inseparable." ${ }^{\text {"25 }}$ To the latter point, the fact that the plaintiff alleged that MS Dealer conspired with the signatory defendant to defraud her was material because such allegation was "intimately founded in and intertwined with the obligations imposed by the [Buyer’s Order]."126

As an initial matter, the first prong in MS Dealer could arguably accord with traditional estoppel in that it conditions its application upon a plaintiff's unreasonable reliance on a written agreement in asserting a claim against a nonsignatory-creating what is tantamount to an implicit unreasonable representation. This test is problematic, though, because it distorts traditional estoppel via its second prong. As one commentator notes, the second prong "contains no requirement that the action against the nonsignatory relate in any way to the agreement containing the arbitration provision, instead allowing the nonsignatory to take advantage of the provision if it makes allegations of 'substantially interdependent and concerted misconduct." "127 In that way, the latter prong fails to consider the nature of traditional equitable estoppel, as well as the other potential consequences presented by asserting such a broad proposition.

As noted, LaForge illustrates that this version of equitable estoppel both confuses the parties at controversy and is emphatically not a product of ordinary contract law. ${ }^{128}$ Regarding the first issue, LaForge shows that some courts, in applying the MS Dealer test, effectively confuse the actual parties at controversy by looking to actions of reliance of a hypothetical signatory party in order to find the necessary element of estoppel satisfied. ${ }^{129}$ This approach "bind[s] both [actual signatory] parties to arbitrate their contract-related claims against the world-at-large, not just each other." ${ }^{\prime 30}$ On the second issue, the misrepresentation requirement is lacking in the MS Dealer test because that element essentially "considers only the plaintiff's claims," vitiating the need for an actual representation. ${ }^{131}$ That is, under the concerted misconduct prong created by MS Dealer, courts view the nonsignatory party as effectively stepping into

124. Id. at 947-48.

125. Id. at 948 .

126. Id. (quoting Boyd v. Homes of Legend, Inc., 981 F. Supp. 1423, 1433 (M.D. Ala. 1997)).

127. Christopher Driskill, Note, A Dangerous Doctrine: The Case Against Using Concerted-Misconduct Estoppel to Compel Arbitration, 60 ALA. L. REV. 443, 453 (2009).

128. LaForge, supra note 4, at 245.

129. Id. at 243 (citing Grigson v. Creative Artist Agency, L.L.C., 210 F.3d 524, 527 (5th Cir. 2000)).

130. Id. at 245.

131. Id. at 244. 
the shoes of a third-party signatory. ${ }^{132}$ Extending this analysis, the nonsignatory again becomes a hypothetical signatory who "sought to avoid [the costs and expenses of litigation] by including the arbitration provision in its agreement ...."133 Yet this approach does not adequately consider the conduct of the parties directly at controversy because those parties had no agreement. As LaForge reasons, "[w] here traditional estoppel considers the conduct of both parties ... [ [this version] of estoppel makes an equitable determination by looking only at the plaintiff's claims. . . . [but fails to] adequately determine what is equitable in . . . the relationship between the nonsignatory defendant and plaintiff . ....”134

While the Eleventh Circuit eventually suggested that a party had to satisfy both prongs of the MS Dealer test in order to permit a nonsignatory to compel arbitration, ${ }^{135}$ many courts have subsequently neglected to impose such a restraint. ${ }^{136}$ Moreover, those courts utilizing the MS Dealer approach seem to effectively assume that because defendants are entitled to

132. Id. at 250 .

133. Id.

134. Id. at 252.

135. Driskill, supra note 127 , at 455 (discussing In re Humana, Inc. Managed Care Litig., 285 F.3d 971 (11th Cir. 2002)).

136. See, e.g., Palmer Ventures, L.L.C. v. Deutsche Bank AG, No. 06-30584, 254 Fed. Appx. 426, 429 (5th Cir. 2007) (permitting a nonsignatory to compel under an application of the MS Dealer test and noting that the test permits such a result under either prong); see also In re Merrill Lynch Trust Co. FSB, 235 S.W.3d 185, 193-94 (Tex. 2007) (“Merrill Lynch”) (discussing federal cases permitting parties to compel arbitration under the concerted misconduct prong and suggesting that these courts would effectively "sweep independent entities and even complete strangers into arbitration agreements").

Other circuits have applied equitable estoppel tests similar to the second prong of MS Dealer. Specifically, some courts have permitted nonsignatories to compel arbitration where a plaintiff's claims against multiple defendants satisfy the "'intertwined-claims' test." Merrill Lynch at 193. An example of this test can be found in Ross v. American Express, 478 F.3d 96, 97 (2d Cir. 2007). In Ross, the plaintiffs filed class action suits against various credit card companies, including American Express, alleging "violations of the Sherman Act arising from an alleged conspiracy to fix fees for the conversion of foreign currencies." Ross at 97 . The district court held that nonsignatory defendants were permitted to take advantage of the arbitration clauses contained in the plaintiffs' contracts with the other credit card companies under the doctrine of equitable estoppel because the issues in both cases were "inextricably intertwined," but denied the motion to compel on other grounds, leading to an appeal. Id. at 98 (citing Ross v. Am. Express Co., 2005 U.S. Dist. LEXIS 21084 at *10). The Second Circuit held that it had jurisdiction under $\S 16(a)(1)$ of the FAA to hear the appeal from the district court's denial of the nonsignatory-defendant's motion to compel, notwithstanding the absence of a written agreement to arbitrate with the plaintiffclass. Id. at 99. The court noted that appellate jurisdiction over the denial was based on the principle that ordinary contract law presumptively governs arbitration under the FAA, and equitable estoppel is an essential tenant of ordinary contract law. Id.

This approach, though, has been interpreted to contain a requirement tantamount to the first prong of MS Dealer - namely, that the parties have a close enough relationship that the initial claims are based in part on the obligations under the contract containing the arbitration clause. See Merrill Lynch, 235 S.W.3d at 193-94. 
the benefit of the arbitration clause, the requirement of a written agreement to arbitrate under $\S \S 3$ and 4 of the FAA is implicitly satisfied. ${ }^{137}$ In line with Professor Sternlight's reasoning, however, bestowing the benefit of an arbitration agreement on a party who was not a signatory, and who did not detrimentally rely on a misrepresentation, unfairly usurps the other party's right of access to the courts without so much as considering inequity or constitutional implication.

In sum, allowing a nonsignatory defendant to compel arbitration or to stay litigation under this formulation of the MS Dealer application of equitable estoppel fails to consider the underlying theoretical basis of traditional estoppel and, as LaForge concludes, leads to "inequitable results," at least where concerted misconduct is all that is alleged. ${ }^{138}$ The plaintiff's right to jury trial falls by the wayside of efficiency considerations and federal pro-arbitration policy. ${ }^{139}$ Finally, as discussed in the following section, it is unlikely that a waiver argument changes the ultimate result of a Seventh Amendment violation in these instances.

\section{Waiver}

The right to trial by jury may, like other constitutional rights, be waived. ${ }^{140}$ This proposition has obvious implications for agreements to arbitrate. Accordingly, a discussion of jury trial waiver jurisprudence and its effect on arbitration clauses is necessary.

Federal courts vary in their treatment of jury trial waivers. ${ }^{141}$ When assessing the validity of any waiver of a constitutional right, courts apply

137. See, e.g., Realty Trust Group, Inc. v. Ace Am. Ins. Co., 2007 U.S. Dist. LEXIS 91331, at *9 (S.D. Miss. Dec. 11, 2007) (discussing how the factors of the MS Dealer test relate to the requirement of a plaintiff's reliance on a written agreement).

138. See infra Section III.C.

139. LaForge interestingly notes the rhetoric of one court that reiterated the proarbitration policy in applying the second prong of MS Dealer. See LaForge, supra note 4, at 244 (noting that, in Grigson, the court "repeats the shibboleth that arbitration is favored in [the] law" by suggesting that "unless the plaintiff is estopped from litigating its claims against the nonsignatory defendant, the 'federal policy in favor of arbitration [will be] effectively thwarted.”’ (quoting Grigson v. Creative Artists Agency, L.L.C., 210 F.3d 524, 527 (5th Cir. 2000))).

140. See Melissa Briggs Hutchens, At What Costs?: When Consumers Cannot Afford the Costs of Arbitration in Alabama, 53 AlA. L. REV. 599, 602 n. 23 (2002) (explaining that the federal right to a jury trial can be waived) (citing JOHN E. NOWAK \& RONALD R. ROTUNDA, CONSTITUTIONAL LAW § 13.8, at 585 nn.10-11 (6th ed. 2000)).

141. Andrew M. Kepper, Note, Contractual Waiver of Seventh Amendment Rights: Using the Public Rights Doctrine to Justify a Higher Standard of Waiver for Jury-Waiver Clauses than for Arbitration Clauses, 91 IowA L. REv. 1345, 1348 (2006) (citing Jean Sternlight, Mandatory Binding Arbitration and the Demise of the Seventh Amendment Right to a Jury Trial, 16 OHIO ST. J. ON Disp. Resol. 669, 675 (2001)). 
different standards. ${ }^{142}$ Specifically, if the right to a jury trial in a civil case is to be waived, it typically must be done so knowingly and voluntarily. ${ }^{143}$

While it is unclear whether the "knowing and voluntary" standard has ever applied to waivers in contracts containing only arbitration clauses but no explicit jury-waiver clauses, many commentators appear to recognize that most courts apply a more lenient waiver standard to arbitration agreements. ${ }^{144}$ Indeed, courts tend to view the "loss of the right to a jury trial ... [as] a necessary and fairly obvious consequence of an agreement to arbitrate." 145

Because the FAA employs general state contract law principles to ascertain the validity of arbitration clauses in the first instance, ${ }^{146}$ many courts assume that one loses their right to a jury trial solely upon a minimal showing of mutual assent to enter into an underlying agreement containing such a clause. ${ }^{147}$ To this end, as another commentator puts it, "courts find consent to arbitration, not through the actual intentions or understandings of the parties, but by looking at whether a reasonable person would believe that an agreement to arbitrate had been reached."148

Professor Sternlight cogently explains that the vast majority of courts simply "conclude that the jury trial doctrines are not relevant" to arbitration clauses because of the federal policy favoring arbitration. ${ }^{149}$ She further argues that the "knowing and voluntary" standard applied to jury trial waiver clauses in general should be applied in the arbitration context. ${ }^{150}$ That courts use the federal policy favoring arbitration as an excuse not to,

142. Id.; see also Commodity Futures Trading Comm’n. v. Schor, 478 U.S. 833, 848 (1989) ("Article III does not confer on litigants an absolute right to the plenary consideration of every nature of claim by an Article III court.").

143. See Leasing Service Corp. v. Crane, 804 F.2d 828, 832 (4th Cir. 1986) (noting that the right to jury trial under the Seventh Amendment, while fundamental, "can be knowingly and intentionally waived by contract”); accord RDO Fin. Servs. Co. v. Powell, 191 F. Supp. 2d 811, 813 (N.D. Tex. 2002) (reasoning that the "federal standard for determining the validity of a contractual waiver of the right to a jury trial is . . . whether the waiver was made in a knowing, voluntary, and intelligent manner”); $c f$. Cooper v. MRM Inv. Co., 367 F.3d 493, 506 (6th Cir. 2004) (stating that while waivers should be knowingly and voluntarily given, not every contract need mandate a waiver expressly).

144. See Kepper, supra note 141, at 1351-55 ("In contrast to jury-waiver clauses, federal courts generally do not employ a knowing and voluntary standard when determining the validity of arbitration clauses.”); see also Sternlight, supra note 141, at 698-99 (noting that most courts have applied objective contract rules on assent to arbitration clauses).

145. Pierson v. Dean, Witter, Reynolds, Inc., 742 F.2d 334, 339 (7th Cir. 1984) (refusing to find that an arbitration clause contained in a contract was unconscionable despite the fact that the plaintiffs challenging it claimed that they were unaware of its implied limitations).

146. 9 U.S.C. § 2 (2006).

147. Kepper, supra note 141, at 1351.

148. Id.

149. Sternlight, supra note 141 , at 711-13.

150. Id. 
she contends, "is, quite simply, a non-explanation, because the Constitution is the Supreme Law of the Land." 151

Professor Sternlight's argument that the "knowing and voluntary" standard should apply uniformly is compelling because courts consistently fail to offer convincing explanations for why a federal statute seemingly dwarfs a constitutional right. Moreover, Professor Sternlight's illustration of these problems is amplified with respect to arbitration clauses contained in unfairly-imposed consumer contracts, ${ }^{152}$ but there are distinctions between the implications of the right to a jury trial with respect to these latter agreements, and those that simply cannot be said to have been products of a true "meeting of the minds."

It is axiomatic that forcing a plaintiff to arbitrate with a nonsignatory under the noted misapplication of equitable estoppel appears to implicate the Seventh Amendment because the plaintiff under these circumstances cannot be said to have knowingly or intelligently waived his right to trial by jury. However, neither can he be said to have waived this right under the mutual assent standard. That is because, in these cases, there is not an underlying agreement between the parties at issue. ${ }^{153}$ The absence of such an agreement necessitates the inference that plaintiffs who are forced to arbitrate with nonsignatory-defendants in cases applying the MS Dealer test never actually waived their right to a jury trial. ${ }^{154}$

\section{CONCLUSION}

By refusing to limit the ability of nonsignatories to avail themselves of arbitration clauses under the FAA, the Court's decision in Carlisle may have a wider impact than Justice Scalia intended. This is because his opinion has implicitly sanctioned the discretionary capacity of district judges to continue applying inequitable third-party theories in the

151. Id. at 716 .

152. Sternlight, supra note 100 , at 22-24.

153. See supra Section III.B. (discussing how the right to jury trial is implicated in equitable estoppel cases).

154. See, e.g., Driskill, supra note 127, at 456-60 (discussing courts that have permitted nonsignatories to compel arbitration under the second prong of the MS Dealer test). On a related note, under Professor Sternlight's suggestion that binding arbitration clauses contained in unfairly imposed consumer contracts could potentially constitute a violation of an individual's Seventh Amendment rights, it is reasonable to infer that, at least in many cases presenting these circumstances, a litigant may have realistically had no intention of agreeing to such an arbitration clause. However, the argument that an individual's Seventh Amendment rights are violated in cases where a nonsignatory is able to compel another to arbitrate pursuant to a misapplication of equitable estoppel carries force because of its palpable inequity. A signatory party in the latter case simply never entered into an agreement, and has little capacity, a fortiori, of preventing or anticipating the result. 
arbitration context that can usurp a plaintiff's right to jury trial. ${ }^{155}$ In illustration of this aspect, decisions like MS Dealer have established that a nonsignatory to an arbitration agreement can unfairly compel arbitration under a misapplication of the doctrine of equitable estoppel. ${ }^{156}$ A plaintiff under these circumstances cannot anticipate having to arbitrate with a nonsignatory-defendant pursuant to the MS Dealer test because under its application of equitable estoppel, the plaintiff's claims need not evidence consent to arbitrate and there is no definite requirement that the plaintiff unreasonably rely on any agreement in asserting his claims. Further, there is no requirement that he make a misrepresentation upon which the nonsignatory detrimentally relied. Finally, because no agreement between the parties exists, the argument for waiver appears weak. It seems that, at least in some cases, this approach may conceivably deny plaintiffs their Seventh Amendment right to a jury trial.

155. See supra Section III.A. (explaining how the federal pro-arbitration policy sometimes usurps the right to trial by jury).

156. See, e.g., Sourcing Unlimited, Inc. v. Asimco Int'l, Inc., 526 F.3d 38 (1st Cir. 2008). 